\title{
The Impact of Institutional Quality and Development of Human Resources on Exports in the West African Economic and Monetary Union (WAEMU) Countries
}

\author{
Zakaya Ramde ${ }^{1 *}$ \\ Chamber of Commerce and Industry of Burkina Faso, 01 BP 502 Ouaga 01, Burkina Faso
}

\begin{abstract}
This study examined the relationship between export, institutional quality and human resources development in WAEMU countries.

Panel data specification were used over the period 1990-2005 and allowed the use of error correction modeling (VECM). The results reveal a long-term relationship between export, institutional quality and human resources development. In a short term perspective, they also show that human resources and institutional quality have positive significant impact for exports development in WAEMU area.

Therefore, these results show the need of policies to improve human resources development and strengthen institutional quality to impact exports flows of WAEMU countries, especially the rule of law of countries, governance stability and developed existing anti-corruption strategies.
\end{abstract}

Keywords: Institutional quality - Human resources - Panel VECM - WAEMU

DOI: $10.7176 / \mathrm{JESD} / 11-12-07$

Publication date:June 30th 2020

\section{Introduction:}

The majority of African countries have economies that are outward-looking. For most of them, they ae sufficient of raw materials, which they export to earn foreign exchange for development in certain domains of their economies. In this way, exports are an important tool of economic policy.

In West Africa, the first export products are raw materials with low human contribution of quality (gold in Burkina Faso, cocoa in Ivory Coast, etc). In most cases, foreign direct investment underpins production in sectors that are low in quality of human resources. The Human Development Index, which aggregate three (3) index as education level of the population aged $15+$, remains relatively low in these countries. This is characteristic of a less qualified workforce for the production of goods and services so a weakness in exports flows.

Costinot (2009) shows that countries with skilled human resources and quality of institutions have comparative advantages that can positively impact their export performance.

Moreover, the quality of the institutions appears as a necessary condition to a better production and better returns of their exports. Credibility of institutions are guaranties of foreign investment in the economy that can lead to economic prosperity North D (1990). On the other hand, advanced exports can deteriorate institutions in countries considered as economically weak Levchenko A (2009). Several indicators measure the quality of institutions. However, stability in governance, clear rules of law over property rights, and minimal corruption can increase the productivity of economies and increase exports. If we consider that the quality of human resources as well as stable institutional frameworks can impact the level of production of economies, and hence indirectly boost export, then we can look for questions of link that can exist between them.

\section{Methodology:}

2.1 Data

Data use in our model are exports, human development index and institutional quality. Exports represents exports of good and services in \% of GDP. Exports data from World Development Indicators. Human resources development comes from human development index database. Institutional quality data comes from ICRG international country risk guide presented by the PRS political risk service group. It is the medians of three (3) variables which are corruption, rule of law and governance stability.

\subsection{Panel data specification}

We use panel data specification for West African economic and Monetary Union (Waemu) gives by this specification:

Exports $_{i, t}=\alpha_{0}+\beta$ Human Ressources Development ${ }_{i, t}+$ SInstitutional Quality $_{i, t}+\eta_{i}+\lambda_{t}+\epsilon_{i, t}$ Where $\eta_{i}$ shows country specific effect and $\lambda_{t}$, temporal specific effect and $\epsilon_{i, t}$ terms of error.

The $i$ and $t$ represents respectively the country and time.

\footnotetext{
${ }^{1}$ Statistician engineer, Economist
} 
The econometric model process follows three (3) steps. Firstly, the homogeneity test of HSIAO is made to prove evidence of nature to perform a panel treatment approach. Looking for the results of the test, $\mathrm{P}$-value of $\mathrm{H}^{1} 0$ is $4.818 \mathrm{e}-20$ which is low than 0.05 . This shows that alpha and beta are not identities. And then, $\mathrm{P}$-value of $\mathrm{H}^{2} 0$ is 0.11065515 which is higher than 0.05 . So we cannot reject the beta coefficients of explicative variables are equal for different countries. The P-value of $\mathrm{H}^{3} 0$ is very low than 0.05 . This shows existence of specific effects.

Table 1: Hsiao test

\begin{tabular}{|l|l|l|}
\hline Hypothesis & F-stat & P-value \\
\hline $\mathrm{H}^{1} 0$ & 13.434427 & $4.818 \mathrm{e}-20^{* *}$ \\
\hline $\mathrm{H}^{2} 0$ & 1.4558271 & 0.11065515 \\
\hline $\mathrm{H}^{3} 0$ & 55.35322 & $9.440 \mathrm{e}-30 * *$ \\
\hline
\end{tabular}

Note: significance at $5 \%$.

\subsection{Unit root test}

In other parts, we will discuss on stationarity of variables. The analysis of stationarity of exports, human resources development and institutional quality is necessary before econometric application, indeed, to avoid wrong regressions. The tests proposed by Levin-Lin-Chu (2002) and Im-Pesaran-Shin (2003) will be use to find the order of our series in panel.

The two (2) tests shows that we cannot reject the null hypothesis of a unit root for Exports (X), Human Resources Development (HDI) and Institutional Quality (IQ) at 5\% level of significance. The P-values obtained are less than $5 \%$. So these variables are not stationary at level.

Table 2: Unit root test (in level)

\begin{tabular}{|l|l|l|l|l|l|}
\hline & Test Im-Pesaran-Shin & Test de Levin-Lin-Chu \\
\hline & Intercept & Intercept+trend & Intercept & Intercept+trend & None \\
\hline $\mathrm{X}$ & $0.0006^{*}$ & $0.0260^{*}$ & $0.0000^{*}$ & $0.0000^{*}$ & 0.3080 \\
\hline $\mathrm{HDI}$ & 1.0000 & 0.4326 & 1.0000 & 0.9921 & 1.0000 \\
\hline $\mathrm{IQ}$ & $0.0069^{*}$ & 0.9981 & $0.0009^{*}$ & 0.7702 & 0.3756 \\
\hline
\end{tabular}

But, after differencing them at one time, the null hypothesis of existence of a unit root was rejected at $5 \%$ level of significance for both tests, and then we conclude at the stationarity of these variables at their first difference.

Table 3: Unit root test (in difference)

\begin{tabular}{|c|c|c|c|c|c|}
\hline & \multicolumn{2}{|c|}{ Test Im-Pesaran-Shin } & \multicolumn{3}{|c|}{ Test de Levin-Lin-Chu } \\
\hline & Intercept & Intercept+trend & Intercept & Intercept+trend & None \\
\hline $\mathrm{X}$ & $0.0000^{*}$ & $0.0000 *$ & $0.0000^{*}$ & $0.0000 *$ & $0.0000^{*}$ \\
\hline HDI & $0.0080 *$ & 0.1 & $0.0000 *$ & $0.0000 *$ & $0.0202 *$ \\
\hline IQ & $0.0005^{*}$ & $0.0000 *$ & $0.0000 *$ & $0.0000 *$ & $0.0000 *$ \\
\hline
\end{tabular}

Note: * means statistically significant at $5 \%$ level of significance.

Source : Our construction on Eviews.

And then, they are integrated at order one I(1). And then, the variables are eligible to test the long run cointegration analysis between them.

\subsection{Trace, max-eigen and Pedroni tests of cointegration \\ - $\quad$ Trace and max-eigen tests}

According to Trace test, one (1) cointegrating equation at the level of 5\% were accepted. The P-values from trace test and max-eigen statistic are significant at 5\% level. This shows existence of a long-run relationship between X, HDI and IQ.

Table 4: Trace Test for cointegration

\begin{tabular}{|l|l|l|l|l|}
\hline & Trace test & P value & Max-eigen test & P value \\
\hline None & 55.14 & 0.0000 & 62.48 & 0.0000 \\
\hline At most 1 & 9.906 & 0.7690 & 10.76 & 0.7049 \\
\hline At most 2 & 10.67 & 0.7120 & 10.67 & 0.7120 \\
\hline
\end{tabular}

\section{- Predroni test}

Pedroni(2004) is used to test cointegration. And then, as results shows, four (4) of seven (7) statistics gives by Pedroni test concluded on existence of cointegration relation between exports, human ressources development and institutional quality. And then, according to Granger representation theorem, an vector error correction model (ECM) can be perform. 
Table 5: Pedroni test for cointegration

\begin{tabular}{|c|c|c|c|c|}
\hline \multicolumn{5}{|c|}{ Alternative hypothesis: common AR coefs. (within-dimension) } \\
\hline & Statistic & $\mathrm{P}$ value & $\begin{array}{l}\text { Weighted } \\
\text { Statistic }\end{array}$ & $\mathrm{P}$ value \\
\hline Panel v-Statistic & -1.079967 & 0.8599 & -1.079967 & 0.8599 \\
\hline Panel rho-Statistic & -1.350867 & 0.0884 & -1.350867 & 0.0884 \\
\hline Panel PP-Statistic & -2.428329 & 0.0076 & -2.428329 & 0.0076 \\
\hline Panel ADF-Statistic & -1.908328 & 0.0282 & -1.908328 & 0.0282 \\
\hline \multicolumn{5}{|c|}{ Alternative hypothesis: individual AR coefs. (between-dimension) } \\
\hline & Statistic & $\mathrm{P}$ value & & \\
\hline Group rho-Statistic & -0.242182 & 0.4043 & & \\
\hline Group PP-Statistic & -2.679863 & 0.0037 & & \\
\hline Group ADF-Statistic & -1.873918 & 0.0305 & & \\
\hline
\end{tabular}

\section{Result:}

\section{Cointegration equation}

Cointegration equation is given by : $\quad X=-39,073 \mathrm{HDI}+2,011$ IQ

On the long term, HDI have negative impact to X, exports and IQ have positive impact on $\mathrm{X}$. Table 6: Estimation of VECM model

\begin{tabular}{|c|c|c|c|}
\hline & $\mathrm{D}(\mathrm{X})$ & $\mathrm{D}(\mathrm{HDI})$ & $\mathrm{D}(\mathrm{IQ})$ \\
\hline CointEq1 & $\begin{array}{r}-1.573054 \\
(0.09191) \\
{[-17.1157]}\end{array}$ & $\begin{array}{c}-4.39 \mathrm{E}-05 \\
(0.00029) \\
{[-0.14945]}\end{array}$ & $\begin{array}{c}-0.053147 \\
(0.02070) \\
{[-2.56806]}\end{array}$ \\
\hline $\mathrm{D}(\mathrm{X}(-1))$ & $\begin{array}{c}0.269332 \\
(0.06964) \\
{[3.86726]}\end{array}$ & $\begin{array}{c}0.001165 \\
(0.00022) \\
{[5.24060]}\end{array}$ & $\begin{array}{r}-0.004773 \\
(0.01568) \\
{[-0.30436]}\end{array}$ \\
\hline $\mathrm{D}(\mathrm{HDI}(-1))$ & $\begin{array}{c}203.9609 \\
(32.5102) \\
{[6.27375]}\end{array}$ & $\begin{array}{c}0.187286 \\
(0.10381) \\
{[1.80403]}\end{array}$ & $\begin{array}{c}6.162952 \\
(7.32048) \\
{[0.84188]}\end{array}$ \\
\hline $\mathrm{D}(\mathrm{IQ}(-1))$ & $\begin{array}{c}5.053402 \\
(0.47897) \\
{[10.5505]}\end{array}$ & $\begin{array}{c}-0.006198 \\
(0.00153) \\
{[-4.05204]}\end{array}$ & $\begin{array}{r}0.430450 \\
(0.10785) \\
{[3.99110]}\end{array}$ \\
\hline C & $\begin{array}{c}-1.120724 \\
(0.19647) \\
{[-5.70437]}\end{array}$ & $\begin{array}{c}0.004708 \\
(0.00063) \\
{[7.50359]}\end{array}$ & $\begin{array}{r}-0.014155 \\
(0.04424) \\
{[-0.31996]}\end{array}$ \\
\hline $\begin{array}{l}\text { R-squared } \\
\text { Adj. R-squared } \\
\text { Sum sq. resids } \\
\text { S.E. equation } \\
\text { F-statistic } \\
\text { Log likelihood } \\
\text { Akaike AIC } \\
\text { Schwarz SC } \\
\text { Mean dependent } \\
\text { S.D. dependent }\end{array}$ & $\begin{array}{r}0.811807 \\
0.803713 \\
88.84066 \\
0.977382 \\
100.2933 \\
-134.2479 \\
2.841795 \\
2.973681 \\
-0.050254 \\
2.206064\end{array}$ & $\begin{array}{c}0.344799 \\
0.316618 \\
0.000906 \\
0.003121 \\
12.23530 \\
428.9286 \\
-8.651604 \\
-8.519718 \\
0.005714 \\
0.003775\end{array}$ & $\begin{array}{r}0.189686 \\
0.154834 \\
4.504555 \\
0.220082 \\
5.442598 \\
11.85806 \\
-0.139960 \\
-0.008074 \\
0.017857 \\
0.239394\end{array}$ \\
\hline $\begin{array}{l}\text { Determinant resid } \\
\text { Determinant resid } \\
\text { Log likelihood } \\
\text { Akaike informatic } \\
\text { Schwarz criterion }\end{array}$ & $\begin{array}{l}\text { nce (dof adj.) } \\
\text { nce } \\
\text { on }\end{array}$ & $\begin{array}{r}2.36 \mathrm{E}-07 \\
2.01 \mathrm{E}-07 \\
338.3399 \\
-6.537548 \\
-6.062758\end{array}$ & \\
\hline
\end{tabular}




\subsection{The long run causality}

The OLS (ordinary least squares) method were used to discuss about the significance of the model. We found that the error correction term C(1) which is -1.57 is negative and significant at the level of $5 \%$ because of -17.11 statistic which is low 0.09. So there is a long-run relationship between the three (3) variables. Then, it exists an impact in long-term between exports flows, human resources and institutional quality.

\subsection{The short run causality}

The wald test were conducted to determine the significance of coefficients.

\section{- Human resources development}

According to the short term causality results, the $p$ value statistic associated to $C(3)$ is lower than 0.05 . So the coefficient is significant at the $5 \%$ level. We can consider human resources development explains exports flows in short term.

\section{- Institutional quality}

As we can see, the p value statistic associated to C(4) is lower than 0.05 . So the coefficient is significant at the $5 \%$ level. We consider that institutional quality explains exports flows in short term in WAEMU countries.

Table 7 : Estimation of VECM model

\begin{tabular}{|l|l|l|l|l|}
\hline & Coefficient & Std. Error & t-Statistic & Prob. \\
\hline C(1) & -1.573054 & 0.091907 & -17.11567 & 0.0000 \\
\cline { 2 - 5 } C(2) & 0.269332 & 0.069644 & 3.867262 & 0.0002 \\
\cline { 2 - 5 }$(3)$ & 203.9609 & 32.51020 & 6.273751 & 0.0000 \\
\cline { 2 - 5 } C(4) & 5.053402 & 0.478971 & 10.55053 & 0.0000 \\
\cline { 2 - 5 } C(5) & -1.120724 & 0.196468 & -5.704366 & 0.0000 \\
\hline R-squared & 0.811807 & Mean dependent var & -0.050254 \\
\hline Adjusted R-squared & 0.803713 & S.D. dependent var & 2.206064 \\
\hline S.E. of regression & 0.977382 & Akaike info criterion & 2.841795 \\
\hline Sum squared resid & 88.84066 & Schwarz criterion & 2.973681 \\
\hline Log likelihood & -134.2479 & Hannan-Quinn criter. & 2.895140 \\
\hline F-statistic & 100.2933 & Durbin-Watson stat & 2.278503 \\
\hline Prob(F-statistic) & 0.000000 & & & \\
\hline
\end{tabular}

\subsection{Granger causality}

According to Granger causality test, we rejected that IQ does not Granger cause HDI. We also reject HDI does not Granger cause $\mathrm{X}$ and also $\mathrm{X}$ does not Granger cause HDI were rejected. So there is a relation of causality of IQ on HDI, HDI on $\mathrm{X}$ and $\mathrm{X}$ on HDI.

Table 9: Granger causality

\begin{tabular}{|l|c|l|l|}
\hline Null Hypothesis: & Obs & F-Statistic & Prob. \\
\hline X does not Granger Cause IQ & 105 & 0.00144 & 0.9698 \\
\hline IQ does not Granger Cause X & & 0.01048 & 0.9187 \\
\hline HDI does not Granger Cause IQ & 105 & 0.78679 & 0.3772 \\
\hline IQ does not Granger Cause HDI & & 4.71742 & 0.0322 \\
\hline HDI does not Granger Cause X & 105 & 5.31028 & 0.0232 \\
\hline X does not Granger Cause HDI & & 6.71723 & 0.0109 \\
\hline
\end{tabular}

\section{Discussion and Conclusion:}

The objective of this study was to analyze the impact of institutional quality and human ressources development on exports flows in WAEMU countries. Based on data from Human Development Index, World Development Indicators and PRS Group over the period 1990-2005, an vector error-correction were build and gives two (2) results. Firstly, there is a long-term relationship between exports flows, human ressources development and institutional quality. The institutional quality and human ressources have positive impact on short term on exports. Secondly, institutional quality implies a better human ressources development as exports too, and a qualified human ressources implies exports in WAEMU areas.

\section{References:}

1. North D. (1990), Institutions, Institutional Change and Economic Performance, Cambridge University Press and Robert Donnelly Review Essay

2. Muhammad TM and Eatzaz A (2006). Determinants of Exports in Developing Countries. Pakistan Institute of Development Economics; Institute of Development Economics (Pakistan) 
3. Levchenko A (2009). Trade, Inequality and the Political Economy of Institutions. 